\title{
On some Aspects of Life Writing in Bernard Kangro's Kuus päeva and Seitsmes päev ${ }^{1}$
}

\author{
MAARJA HOLLO
}

\begin{abstract}
The Second World War cleft Estonian literature into two halves for half a century: the literature of the homeland and the literature of the diaspora. Bernard Kangro (1910-1994), who fled Estonia in 1944, was a prolific writer, the editor of the magazine Tulimuld and the head of the main diaspora publishing house Eesti Kirjanike Kooperatiiv. Kuus päeva (Six Days, 1980) and Seitsmes päev (The Seventh Day, 1984) are Kangro's last novels. Kangro began drawing up plans for these two novels at the beginning of the 1970s, when western scholars were taking a deeper interest in life writing. From the perspective of form, Kangro's novels have a special status in Estonian literature; in Kuus päeva, Kangro uses the diary form to create a meta-level in the novel with the goal of analyzing the specificity of autobiographical writing; in Seitsmes päev this meta-level is achieved through the imaginary diary of the biographer-protagonist, which consists of his reflections and experiences while writing a biography. These reflections and experiences derive from Kangro's own preliminary research for the historical novel Kuus päeva. Seitsmes päev thus becomes the metatext for Kuus päeva. The main theme of the first novel of the dilogy is the writing of autobiography as such. Through the protagonist Andreas Sunesen, a historical figure, questions are raised concerning the concept of truth in autobiographical writing, the relations between autobiographical writing and historical writing and the function of confessionality in autobiographical narrative. The second focus of this article is on the issues connected to the writing of biography, as thematized in Seitsmes päev. In Kuus päeva, three meanings of the concept of truth can be differentiated: the truth expressed by the autobiographer (which the protagonist also refers to as "eternal truth"); the truth of historical events, which is expressed in their claim to authenticity, their correspondence or harmony with reality; and the truth about the existence of the autobiographer, which should appear as a result of the verbalization of his self-examination and memory work. The story of the mission to the eastern Baltic Sea region contained in Andreas' autobiographical narrative points rather to the inseparability of the first two dimensions of truth, at least to the extent that the narrator of these historical events is also their witness and participant. Thus, it is unavoidable that he would relay what has happened from the vantage point of his present needs and purposes. Kangro's novel seems to support the Italian philosopher Adriana Cavarero's claim about self-narration:
\end{abstract}

1 This article has been written with the support of ESF grants 8530, 9160 and the TF Project Sources of Cultural History and Contexts of Literature. 
HOLLO

the autobiographical narrative can only answer the question of what a person was, not the question of his or her existence. In Seitsmes päev, the second novel of the dilogy, a philosophical question is foregrounded - the question of the task of the biographer. As far as the poetics of this novel is concerned, the answer to this question remains ambivalent.

Keywords: Bernard Kangro; Estonian literature in exile; philosophical aspects of life writing

DOI: http://dx.doi.org/10.12697/IL.2013.18.2.09

Bernard Kangro's last novels Kuus päeva (Six Days, 1980) and Seitsmes päev (The Seventh Day, 1984) have remained marginal in the reception of his works for different reasons, such as the diminishing readership in exile. However, they have a special position in his oeuvre as well as in Estonian literature as a whole. Endel Nirk, one of the few critics who has written an in-depth analysis of these Kangro's late novels, sums up the difficulty of addressing these texts: „They indeed are quite different from what we have been accustomed to call novels." (Nirk 1990: 695) Though others have acclaimed Kangro as an innovator in the form of the Estonian novel (e.g. Annus 1997), Nirk sees his contribution differently, emphasizing the thematic newness of the dilogy, which is visible in a finely-textured presentation of the characters' inner lives. Another distinctive feature of Kangro's last two novels is the central theme of the writing of life into narrative. In Kuus päeva, Kangro is more concerned with the problems of self-narration; in Seitsmes päev, with the writing of biography. In Kuus päeva, Kangro is interested primarily in the workings of autobiographical memory, and its relations on the one hand with historical sources of the time, on the other, with historical writing today. The memories of the protagonist, Andreas Sunesen, an historical personage, are simultaneously a testimony - the testimony of a participant in the same historical events; memories and eyewitness testimony enter into a dialogue with the accounts of the chroniclers of the era and with the writing of history in a broader sense. In addition, it is important to note that as a historical novel, Kangro's text (albeit belatedly, given its publication date in Estonia, 2006) participates in shaping the Estonian reader's historical consciousness. In the course of writing a biography, the protagonist of Seitsmes päev encounters a different problem: the historical personages reawaken, come back to life and talk back, interfering with his interpretations of the past and his knowledge of history. In addition to sharing a theme and an object, Andreas Sunesen, the two novels have a common form: both are metafictions, presented to the reader in the guise of the protagonists' diaries. A number of Estonian writers have made use of the diary form in their novels: Friedebert Tuglas in Felix 
Ormusson (1915), A. H. Tammsaare in Varjundid (Nuances, 1917), Karl Ristikivi in Rooma päevik (Roman Diary, 1971), Enn Vetemaa in Munad Hiina moodi (Eggs Chinese Style, 1972), and Jaan Kross in Keisri hull (The Czar's Madman, 1978). However, no one has made as thorough and far-reaching a use of the diary novel as a genre than Kross and Kangro, who concentrates directly on the processes of life writing. By depicting these processes, Kangro's novels enable us to investigate how a rhetorical illusion of life as a coherent narrative is created, where the events are presented in the form of a meaningful succession with definite orientation, which according to Pierre Bourdieu "is continuously and ceaselessly consolidated by the whole literary tradition” (Bourdieu 2003: 92).

The first part of this article focuses on three aspects of autobiographical narrative: the concept of truth, the relationship between autobiographical writing and historical writing, and the function of confession in such a narrative. The second focus of this article is on the issues connected to the writing of biography, as thematized in Seitsmes päev.

\section{Truth in Autobiography}

The paradoxical relationship of a person with his or her memory is vividly described in the poem entitled "Birthday", written by Fernando Pessoa under one of his heteronyms, Alvaro de Campos. The poem speaks of an elderly man, who on his birthday finds that his memory is empty; he can only recall one event, the celebration of his birthday when he was still a child. Thus all of his past is concentrated into a single birthday memory; because of the emptiness that rules his past, he savours the morsels of this one memory "like hunger bread, and his teeth do not notice the butter" (Pessoa 2009: 38). The symbolic equivalence between remembering and eating hunger bread is an apt characterization of the memory work engaged in by Andreas Sunesen, the protagonist of Kuus päeva, the $13^{\text {th }}$ century archbishop of Lund, who was the papal legate in Scandinavia, and organizer of the eastern Baltic crusade. ${ }^{2}$ When he contracts

2 The historical Andreas Sunesen (ca 1167-1228) was a renowned intellectual and theologian, as mentioned in the chronicles of Arnold of Lübeck and Henry of Livonia (Nielsen 2001: 99). He received an exemplary education, and studied theology and law in Paris, Bologna, and Oxford. Evidence of Andreas' literary interests can be seen in his 8040 line epic Hexaëmeron and his Hymns to Mary, of which no copies survive. His career as a politician and theologian began in the year 1201, when he was elected bishop of Lund. Five years later, Pope Innocentius III commissioned Andreas to enter into combat with the people in the Baltic Sea basin who had not yet received the Christian faith. It is known that Andreas took part in the battle for Saaremaa (Ösel) in 1206 and the battle of Reval in 1219 . 
HOLLO

leprosy, ${ }^{3}$ Andreas is forced to renounce the bishopric in Lund and retreat into exile. Having been cut off from his previous life, Andreas starts keeping a diary, devoting himself to examining and recording his past.

At the beginning of his diary, Andreas reflects on the paradoxes of writing about his life: as a leper, he has already been ritually removed from among the living, and has thereby gained a distanced vantage point from which to regard his past; this privilege is unavailable to those individuals who are still active participants in social life. However, these same factors may act to preclude such retrospective examination: at the time he begins writing, the life Andreas lived prior to his exile - his "real life" - is over. The rhetorical question addressing the impossibility of this task is followed by a vow to speak nothing but the truth, and a confession of his sincerity and unworthiness:

Let it be only the pure truth that - sub specie aeternitatis - I endeavour to record on this parchment. I shall omit nothing and deny nothing, in order that my divine judges not accuse me of hiding the truth. However, I would not want to waste their precious time with mere trifles. My life, the life of a sinner, is full of senseless thoughts, confusing events, bends in the road lined with lies; no one needs to know about these. (Kangro 1980: 14) ${ }^{4}$

In the very next sentence, Andreas' original intention to "tell everything just as it was" gets caught in his self-imposed restriction to minimize himself, a justification for leaving some things in the dark, particularly those things that would cause the reader of the diary to doubt his sincerity. The same caution characterizes the way he recalls his childhood and the time following an attempt to conquer Ösel. He justifies abandoning the exact depiction of the past with lack of time. Thus, Andreas' confession principally diverges from the technology of the self, which according to Michel Foucault came into being in the Early Christianity, and which in the course of confession obligates the subject to discover and verbalize "the most imperceptible movements of the thought" in order to destroy himself/herself "as a real body or a real existence" (Foucault

3 From the Middle Ages to the 20th century, leprosy meant complete isolation from society. Ken Kalling notes that "this disease had a central significance in Christianity as a metaphor of illness and accursedness" (Kalling 2006: 10). According to Jacques le Goff, in the Middle Ages leprosy was regarded as a sign of "sin, especially sexual sin committed during times when sexual relations between partners in marriage were prohibited by the church" (Le Goff 2000: 590).

4 Here and in the following the translation by Tiina Kirss. 
1993: 221-222), because the aim of his confession is - on the contrary - to recreate his former "selves" and to uncover his real existence. As in the case of any autobiographical narrative, this kind of recreation is accompanied by the explanations, justifications and assessments of the past events.

Andreas also broaches the question of truth in one of the next diary entries, setting himself in opposition to the chroniclers among his contemporaries who, "while pursuing one purpose or another have forgotten what they remembered, and remembered what they could not have remembered, because those things did not exist" (Kangro 1980: 43). Here Andreas is no longer speaking of eternal truth, but rather of historical truth, thereby implying that in his own writing, he can allow himself a neutrality inaccessible to the chroniclers, since he is free from all political pressures and has resolved to avoid both the temptation to deny past events and the temptation to compensate his poor memory with inventions.

Scholars of autobiography emphasize that the truth expressed in autobiographical writing is uncertifiable, since the writer is simultaneously in the role of narrator and protagonist, and therefore the writing lies "outside a juridical model of truth or falsehood, as models of the paradoxical status of selfreference have suggested [...]" (Smith \& Watson 2010: 16-17). Indeed, the first quotation, where Andreas presents himself as speaking in the name of eternal truth, points directly to the unwritten rule that every autobiographer tacitly follows - to write only of those events in his life which are not "confusing", and to remain silent about the "bends in the road that are lined with lies". With this claim the function of the concept of truth in his text is made explicit. References to the truth belong to the rhetorical repertoire in Andreas' text, designed to alert the reader that what he has recorded cannot be evaluated on the same scale of truth and falsehood as would be appropriate for historical facts. For Andreas, abstinence from hiding the truth means nothing more or less than his intention to tell his story as best as he can.

Besides the concept of truth, Andreas builds his narrative authority by means of quotations from a range of texts, the style and rhetoric of which he imitates consciously or unconsciously. It remains open to question whether and to what extent this web of allusions conceals something more original, his own individual style of writing, as can be seen in the discourse of his diary. As can often be seen in historical novels, the numerous source texts in Kuus päeva the Bible, the lives of the saints, Augustine's Confessions, the poets of his own age (e.g. Arnaut Daniel), Saxo Grammaticus' The Great Deeds of the Danes point to the historical Andreas' extensive reading, his body of knowledge and erudition, and his understanding of himself as a writer. 
HOLLO

Andreas models his autobiographical narrative on Augustine's Confessions, a core text of the western autobiographical tradition and the main cultural model for writing about the self in the West for hundreds of years. The first sentence of Andreas' diary begins with the first half of the first sentence of the Confessions: "Let me seek you, then, Lord, even while I am calling upon you, and call upon you even as I believe in you [...]" (Augustine 1997). Andreas goes beyond this, however, asking God for more time "in order that I might re-create my world [...]" (Kangro 1980, p. 13) and adds only after that: "Oh, merciful Lord, I am looking for you on the winding wrong paths of my worldly life [...]" (Kangro 1980: 13). Thus, in contrast to Augustine, who appeals to God frequently throughout his text in order to strengthen his faith, reflect upon it and proclaim it publicly, Andreas foregrounds the representation of his life in such a manner that it appears worthy of salvation both in the eyes of God and his human audience. In other words, in Augustine's Confessions the speaker is a convert who has come to the inner conviction that God is truth; Andreas, however, is seeking the truth about his existence believing that it can be found only by recalling and verbalizing his past. As a student of Pierre Abélard ${ }^{5}$ (1079-1142), the most distinguished logician, theologian, and philosopher of the Middle Ages, Andreas seems to have mastered Abélard's "methodical approach", according to which "through doubting we arrive at the question, to the inquiry and - most importantly - [...] through inquiry we achieve truth" (Kangro 1980: 147).

\section{The Diary as Workshop}

According to Philippe Lejeune, the diary novel seeks to reconcile two opposing aesthetics. On the one hand, it actualizes the function of the text as fiction; on the other, though unsuccessfully, it mimics the most important traits of a diary - repetition, the lack of coherence or pertinence, unevenness, implicit meaning, allusions, and the unknowability of the narrative ending (Lejeune 2009: 207). The main goal of the author of Kuus päeva has not been reconciliation between the aesthetics of the novel and the diary, that is, mimicking the mode of writing of the diary, but rather discussion of questions concerning the process of self-narration, thus presenting the reader with one possible strategy

\footnotetext{
5 Among Abelard's best-known works are Sic et non, Dialectica, Introductio ad theologiam, Tractatus in intellectibus, and Historia calamitatum, an autobiography in epistolary form, to which Kangro does not refer explicitly in Kuus päeva, but which might have been a model for writing about the life of Andreas, especially as far as his years of study in Paris are concerned.
} 
for narrativizing a life. Therefore, what is most important is how Andreas' diary mirrors his activities as an autobiographer. Andreas' diary shows that as an autobiographer, Andreas makes use of the same devices and conventions as does a writer, who composes carefully, weighing which episodes to represent in his autobiographical narrative and which ones to leave aside. And yet the narrative does not submit completely to Andreas' intentions: the process of remembering has its own laws.

In Kuus päeva the diary serves as a workshop not only through modelling the activities of the autobiographer in the process of composing a narrative, but also in a broader sense. Scholars of autobiography have indicated that autobiographical discourse contains the discourse of testimony, which "creates existential immediacy for both the writer and the reader" (Bruner 1993: 45). A large part of Andreas' narrative is taken up by his testimony as an eyewitness and participant in historical events. As he situates himself in historical time, he contests stories that have been circulating among the people that were used as evidence in the composition of the official written historical record. The testimonial mode of writing is also relevant when we consider Kuus päeva as a historical novel, a form that provides generous opportunities for raising questions of representation, such as the conversion of legends surrounding historical events into historiography, and ways in which autobiographical memory and autobiographical writing relate to the writing of history.

For example, Andreas' autobiographical narrative often refers polemically to stories about the battle of Reval, legends that are dissonant with his own memories and which thus compel him to present the "correct" version of what really happened. In so doing, he contests the official written account of these events and overturns the legend of God's help in the battle against the pagans:

And so, in brief, this was the course of that miserable battle, about which - two years later when I returned home - I had to listen to tales of heroic deeds and God's own intervention in the battle. [...] Miracles are always possible, but I know of no other miracles in this case than that the Rügensians saved us from being mowed down. (Kangro 1980: 238)

As previously mentioned, Andreas repeatedly sets his own autobiographical account in opposition to the chronicles, but he appeals to the same universal scheme that underlies the chroniclers' historical account, which allows "all uprisings to be represented [...] as rebellions against God's intended world order, the Christian community and the church, thereby excluding the rebels from that Christian community" (Kaljundi 2006: 23). Nevertheless, Andreas' 
HOLLO

portrayal of the missionary work in Estland and Livland is of a more complex texture. Andreas blames the locals' mistrust of the strangers on the Swordbrothers' greed and brutality, but he adds another factor: the local people's incomprehension of the foreigners' language explains their lack of acceptance of the message of God's mercy. In sum, then, Andreas' autobiographical narrative contradicts the chroniclers' image of the pagans as the embodiment of evil and wild by nature; thus, he is forced to admit that he too, conqueror and missionary like the Swordbrothers, failed to "keep in mind that we were setting foot on the land of another people, and that they, too, had a right to live on that land, even if they were blind pagans who lacked the light of faith" (Kangro 1980: 219). Andreas' narrative also diverges from the historical events as told by the chronicles by including a confession, uncovering the similarities between the rhetoric of confession and of testimony.

\section{Autobiography and Confessionality}

According to Jerome Bruner, the verisimilitude and negotiability of autobiographical composition are based on a combination of testimony, interpretation, and attitude (Bruner 1993: 46). By verisimilitude Bruner means the signals given in the autobiographical text of the writer's "obvious honest-mindedness", which in turn depends on how well the writer's role (Bruner uses the word genre here) harmonizes with the facts of his life (Bruner 1993: 46). Bruner uses the word forgivability to explain the negotiability of the autobiography, as expressed by the writer's stance. Negotiability is the writer's ability to seem attractive and worthy of praise in the eyes of the reader (Bruner 1993: 47). I argue that the confessional mode of writing can be considered one of the strategies to achieve negotiability in autobiographical narrative.

Confessionality has accompanied autobiography from its origins, and belongs essentially to such a writing practice. It also has a direct connection with the question of the author's sincerity. In Andreas' narrative confessions occupy the hard-to-determine territory separating his actual states of mind from those of which he seeks to convince his reader. The sincerity of a confession depends on the confessor's willingness to be honest and to resist the temptation to use a multitude of words to justify the error or trespass he is confessing in hindsight. In Andreas' narrative one can follow the struggle between these two impulses: a confessional passage is often ended by a quotation from some other text, which turns the confession into a parable rather than a frank Christian admission.

In his autobiographical narrative, Andreas confesses events connected to his personal life as well as those related to his work as a cleric; the personal events mark emotional and biographical turning points. One of such turning 
points in Andreas' narrative is his meeting with the lepers, which allows him to compare his own biography with that of Jesus. The narrative is as follows: in his youth, Andreas once met three lepers on the road, who stole his money, clothes, and boots, and thereafter asked him to pray for them. After what happened, Andreas confesses that he felt nothing but humiliation and repulsion, but vowed that if God spared him from the disease, he would do everything in his power for their benefit. From Andreas' recollection we learn that he did not heed the robbers' prayer, since he lacked compassion toward those who had stolen from him, but that in so doing he also broke the vow he had made to God. In several previous confessions Andreas had justified his failure to do his duty with deficiencies in his own character; however, this particular confession ends with a quotation from Luke's Gospel, where Jesus prays to God that his own fate be less harsh: "Father, if it is your will, take this cup from me, but let it be your will, not mine!" (Kangro 1980: 27) The rhetorical device of quoting the Bible on the threshold from autobiographical narrative to diary writing signals to the reader that Andreas is uncertain with respect to the accuracy and manner of interpretation of his memories as he proceeds to narrate his life.

In yet another episode in his narrative connected with his youthful infatuation with Barbara, the servant girl at his family's farm, Andreas weaves a biblical episode into a confession. When the girl gives birth to a child, Andreas' mother thinks that Andreas is its father, and Andreas takes responsibility for it. In his diary, Andreas indicates that the child's actual father may have been Andreas' own father. Andreas' memories of his desperate flight from home are accompanied by a sequence of corrections which indicate that he was seeking a more "fitting" explanation for these events, that is, one that would harmonize with his preceding narrative. Again the recollection is anchored by a Biblical quotation:

And when he saw that, he arose, and went for his life, and came to Beer-Sheba, and left his servant there. But he himself went a day's journey into the wilderness, and came and sat under a juniper tree: and he requested for himself that he might die; and said, It is enough; now, O LORD, take away my life; for I am not better than my fathers. Then an angel touched him, and said unto him, Arise and eat. And then he arose, and did eat and drink, and went on the strength of that meat forty days and forty nights unto Horeb the mount of God. So it happened to me that time, when I had journeyed a piece of that road. (Kangro 1980: 95) 
HOLLO

This quote from I Kings not only helps explain the confession concerning Barbara, the purpose of which is to show Andreas as a high-minded and steadfast son, who bears the guilt of his own father; the complete meaning is only revealed through the context provided by the last entry in the diary. At the outset, when Andreas began keeping a diary, his goal had been to gain clarity about his sinfulness, not knowing what God's decision would be after he had finished writing his narrative. The final diary entry, which speaks of Andreas' recovery, also speaks of reaching God and receiving forgiveness. Therefore the writing of autobiographical narrative determines Andreas' life course as much as his life determines this narrative. Here we have reason to recall Cavarero's claim about the autobiographical narrative: the autobiographer cannot create a complete narrative of his or her life, since there is no vantage point from which to regard one's life as a whole. Thus the answer to the question Who am I? can only be "the biographical tale of my story, told by another" (Cavarero 2000: 44).

\section{The Task of the Biographer}

After finishing Kuus päeva, Kangro continued to be interested in the theme of life writing. He develops this theme from a somewhat different vantage point in the second novel of the dilogy, Seitsmes päev, ${ }^{6}$ which is centered on the philosophical question of the task of the biographer. The novel's protagonist, exile writer and amateur historian Linus Asser, is working on the biography of Andreas Sunesen. Linus has read "all the available books, studied archival sources, and often wandered in thought in the landscape as it was before the founding of Lund" (Kangro 1984: 8) and "has reconstructed [Andreas'] life story on the basis of his diary and other materials” (Kangro 1984: 14). Thus, Linus begins his research by embarking on a journey familiar to every biographer - gathering facts about the life of the object of research and assembling these into logical and systematic order. It is only in the last phase of the work, when there is only one chapter remaining to be written, that Linus' eyes are opened to the blank spots in Andreas' life, those periods and events that have not been studied, "about which there are scant facts or no traces at all" (Kangro 1984: 9). One such undiscovered area is Andreas' life after his recovery from leprosy until his death on the island of Ivö. Since there are so few facts, these

6 Kangro at first planned to write a trilogy, but this idea was never fulfilled. In the Bernard Kangro collection of the Estonian Literary Museum's Cultural History Archives, there is a folder containing 277 pages of drafts for the third and last novel under three different titles: Kaheksandal päeval (On the Eighth Day), Üksainus pikköö (A Single Long Night), and Kaheksandas ringis (The Eighth Circle) (EKLA, f310, m 125: 1). The earliest draft is dated from 1984 and the latest from the year 1992. 
topics prove especially inspiring for Linus, as well as giving him greater imaginative freedom.

When representing Linus' activities as a biographer, Kangro focuses primarily on the intention to present a human life as more than an array of facts, but commits himself to solve the mystery of his life. Since Andreas' life and his own are separated by centuries, Linus finds it impossible to ignore the previous work of historians. The sequence of possible events involving Andreas is thus imagined based on the available facts and historical reality, and using these, Linus attempts to create a psychologically plausible character. The process of Linus' imagination is guided by bursts of inspiration that are experienced bodily; such episodes place him outside the time of clocks and calendars, evoking an ongoing interior monologue. Linus frequently uses the term seeing as a synonym for imagining; the biographical imagination could therefore be regarded as the ability to envision the object of the biography at particular moments and in the midst of events as "a subject that is in the process of becoming" (Backscheider 2004: 17). In addition to background knowledge about a certain era, such a capacity to envision also requires an understanding of the intellectual horizons of a person who lived in that era. This question is also among the complex issues of biography and creative writing that Kangro investigates in Seitsmes päev.

Further, the topic of imagination is also discussed in Linus' reflections on the biographer's privilege of establishing living contact with the object of research. After his meeting with the "Duke of Skåne" in the insane asylum, Linus regrets that he lacks the madman's ability to identify completely with a role. "With what facility I could complete the final chapter of my work, the chapter that wraps it all up, perhaps the most important part of the Hexaëmeron Andreas' return to the world and to life!" Linus exclaims (Kangro 1984: 78). According to Paula R. Backscheider, "all biographers must be their subject's advocates, taking up the burden of explaining lives and why they were led as they were" (Backscheider 2004: xv). In this manner, biographers approach their objects so closely that they "see through the subject's eyes, try to feel exactly what hurt about each painful event" (Backscheider 2004: xv). Linus lacks such intimacy with Andreas, since Linus' imaginative capacity is restricted by his own self-consciousness. An even greater effort is required to understand Andreas as a religious enthusiast ${ }^{7}$ - his aspirations, motives, revelations, and

7 I use the term religious enthusiast in the same sense as Johan Huizinga does in his study The Waning of the Middle Ages. Huizinga regards Dionysius the Carthaginian as the fullest example of the religious enthusiast, who "combines the ecstasy of the great mystics, the wildest asceticism, the incessant visions and revelations of one who sees ghosts, and endless activity as a theologian and practical spiritual advisor" (Huizinga 2007: 201). 
moments of spiritual transformation. In his autobiographical narrative, Andreas describes himself as "servant of God, keeper of souls, guardian of the gates of the heavenly kingdom, one who expands its borders" (Kangro 1980: 38). Linus does not deny his own scepticism concerning matters of religion; he admits that one of the consequences of this is that he can pose more questions about Andreas' life than he is able to answer. Questions about Andreas ultimately reach beyond the specifics of his life to the larger question of "what or who a person really is" (Kangro 1984: 62).

Another layer of the biographer's work treated of by the novel Seitsmes päev is the nature of sources used as biographical evidence. Linus' research into Andreas' life is significantly influenced by conversations with Jakob Erlandsen, archbishop of Lund from 1253-1274, who was murdered, but in the novel he is depicted as risen from the dead. Whether there has been a miraculous resurrection, or a historically erudite scoundrel is operating under Jakob's name remains unclear; at any rate Jakob gives Linus believable information not only about Andreas, but about the cityscape in Andreas' time and the place of religion in the lives of people of his time. These conversations allow Linus partial entry into a thought world that his religious scepticism makes inaccessible in any final sense. In his autobiographical narrative, Andreas poses the question "Perhaps one should not seek peace by fleeing from the world into solitude, but rather from the world and from life itself, created by God?" (Kangro 1980: 86-87). Inspired by this question, Linus has construed Andreas, now healed of leprosy, as a man who once again feels enthusiasm to proclaim God's word to the world, but whose life ends in bitter disappointment; upon his return to the world he realises that his life-work has been wasted. Jakob contests Linus' intention to represent Andreas as a sceptic; from Jakob Linus hears that Andreas "never admitted defeat", that "his heart was heavy since it was impossible to be a witness of blood, to win the martyr's crown" (Kangro 1984: 151). The conversations with Jakob also clarify to Linus that Andreas never interpreted his illness as punishment for his sins, but saw it as a gift of God.

Linus' discussions about Jakob can be taken as an indication of the problematics of the trustworthiness of oral sources. They emphasize that narrating a life is above all a relational activity, which not only includes relations between a person, his or her life story, and the biographer (Cavarero 2000: 41), but also the biographer's relations with oral and written sources. Particularly when speaking of the death of the object of research, the narrative must rely almost exclusively on such sources.

While writing Andreas' biography, Linus often recurs to his own past. It becomes apparent that Linus' and Andreas' paths crossed symbolically during Linus' childhood at Uelzenhof manor. The lord of the manor had given 
Linus permission to study the books in the attic, and images from these had taken strong roots in his memory. Thus, Linus has memory pictures of one of Andreas' sigillae and of the Lund cathedral (Kangro 1984: 104). Earlier in the novel, Linus had briefly mentioned his time of convalescence in hospital, leaving the hospital, his subsequent solitary life, and beginning the writing of the biography; Linus has also comparing these events of his personal life to Andreas' return to the world. Another point of congruence between Andreas' life and his own is exile; unlike Andreas, who only spent the last years of his life in exile, Linus refers to himself as Ahasuerus, a wanderer with many exiles, beginning with his status as a child born out of wedlock. Critic Endel Nirk judges Linus Asser to be "almost the writer's alter ego", although Linus' life story more closely approximates that of the Estonian writer in exile Karl Ristikivi than that of Bernard Kangro (Nirk 1990: 694). While the inherent parallels between Linus' and Andreas' lives activate and support Linus' biographical imagination, enabling him to see himself in Andreas' place, they also contain certain directions and emphases of which Linus becomes conscious. Indeed, the reason why Linus wishes to emphasize the part of Andreas' life that follows his recovery, his return to the world, and his subsequent disappointment and bitterness, lies in his own disillusionments and failures. As concerns events in Andreas' life for which Linus can find no factual evidence, and about which his oral source, Jakob, also is silent, the only basis for making decisions is human compassion. Thereby in Linus' eyes Andreas earns "eternal life, his own aeterna vita, for which he longed so deeply" (Kangro 1984: 139).

\section{Conclusion}

Kuus päeva makes visible three fundamental aspects of autobiographical narrative: the concept of truth, the relationship between autobiographical writing and historical writing, and the function of confessionality in autobiography. In Kuus päeva, three meanings of the concept of truth can be differentiated: the truth expressed by the autobiographer (which the protagonist also refers to as "eternal truth"); the truth of historical events, which is expressed in their claim to authenticity, their correspondence or harmony with reality; and the truth about the existence of the autobiographer, which should appear as a result of the verbalization of his self-examination and memory work. The story of the mission to the eastern Baltic Sea region contained in Andreas' autobiographical narrative points rather to the inseparability of the first two dimensions of truth, at least to the extent that the narrator of these historical events is also their witness and participant. Thus, it is unavoidable that he would relay what 
has happened from the vantage point of his present needs and purposes. Kangro's novel seems to support Adriana Cavarero's claim about self-narration: the autobiographical narrative can only answer the question of what a person was, not the question of his or her existence. This is so because in the autobiographical narrative, existence is concealed both by the way in which a person is capable of remembering himself as well as by the occasion of writing, which determines the chosen rhetorical patterns by which the reminiscences will be transmitted. By using the protagonist's diary entries to meditate upon the process of narrativizing a life, of life becoming autobiographical narrative, Kangro casts doubt on a widely disseminated understanding of autobiographical narrative $^{8}$ which equates the narrative with identity and claims that the "I" of autobiographical discourse need not pre-exist the narrative thereof. By representing the reciprocal relations between remembering and writing through Andreas' diary, Kangro shows that the autobiographical "I" is not merely a textual construction, which appears out of nowhere; rather, this "I" precedes the autobiographical narration, and the autobiographical narration is born through the processes of remembering engaged in by that "I".

In Seitsmes päev, the second novel of the dilogy, a philosophical question is foregrounded - the question of the task of the biographer. As far as the poetics of this novel is concerned, the answer to this question remains ambivalent to the end: Linus' manuscript about Andreas is destroyed and at the end of the novel he asks himself whether he should instead have created a legend about Andreas.

\author{
Maarja Hollo \\ fermina22@hotmail.com \\ Eesti Kirjandusmuuseum \\ Eesti Kultuurilooline Arhiiv \\ Vanemuise 42 \\ 51003 Tartu \\ EESTI
}

\footnotetext{
8 Such a position is taken by many scholars, for example, Paul John Eakin (Eakin 1999).
} 
On some Aspects of Life Writing in Bernard Kangro

\section{References}

Annus, E. 1997. Eesti romaani narratiivseid mudeleid. A. H. Tammsaare "Tõe ja õiguse” ning B. Kangro Tartu-romaanide näitel. - J. Undusk, ed., Klassika ja narratiivsus. Tammsaarest Kangroni. Tallinn: Underi ja Tuglase Kirjanduskeskus, $11-58$.

Augustine 1997. The Confessions. New York: New City Press.

Backscheider, P. R. 2004. Reflections on Biography. Oxford: Oxford University Press.

Bourdieu, P. 2003. Praktilised põhjused. Teoteooriast. [L. Tomasberg, transl.] Tallinn: Tänapäev.

Bruner, J. 1993. The Autobiographical Process. - R. Folkenflik, ed., The Culture of Autobiography. Constructions of Self-Representation. Stanford: Stanford University Press, 38-56.

Cavarero, A. 2000. Relating Narratives. Storytelling and Selfhood. London and New York: Routledge.

Eakin, P. J. 1999. How Our Lives Become Stories. Making Selves. Ithaka and London: Cornell University Press.

Foucault, M. 1993. About the Beginning of the Hermeneutics of the Self: Two Lectures at Dartmouth. - Political Theory, Vol. 21, No. 2, 198-227.

Huizinga, J. 2007. Keskaja sügis. [M. Sirkel, transl.] Tallinn: Varrak.

Kaljundi, L. 2006. Hingejõu ilmed ja meelehaigus: mäss eesti ajaloomälus ja selle keskaegsetes tüvitekstides. - M. Hiiemäe, ed., Paar sammukest XXII. Eesti Kirjandusmuuseumi aastaraamat 2005. Tartu: Eesti Kirjandusmuuseum, 15-30.

Kalling, K. 2006. Vari minevikust. Pidalitõbi. - Horisont, 1, 10-17.

Kangro, B. 1980. Kuus päeva. Andreas Sunepoja päevaraamat ja pihtimused. Lund: Eesti Kirjanike Kooperatiiv.

Kangro, B. 1984. Seitsmes päev. Lund: Eesti Kirjanike Kooperatiiv.

Lejeune, P. 2009. The Diary as “Antifiction”. - J. D. Popkin, J. Rak, eds., On Diary. Manoa: University of Hawai'i Press, 201-210.

Le Goff, J. 2000. Keskaja Euroopa kultuur. [M. Ott, transl.] Tallinn: Kupar.

Nielsen, T. K. 2001. The Missionary Man: Archbishop Anders Sunesen and the Baltic Crusade, 1206-21. - A. V. Murray, ed., Crusade and Conversion on the Baltic Frontier 1150-1500. Aldershot: Ashgate, 95-117.

Nirk, E. 1990. Bernard Kangro hilisromaanidest. - Looming, 5, 690-695.

Pessoa, F. 2009. Tubakapood. Álvaro de Campose viimased luuletused. [T. Õnnepalu, transl.] Tallinn: Pilgrim.

Smith, S., Watson, J. 2010. Reading Autobiography. A Guide for Interpereting Life Narratives [2. Edition]. Minneapolis, London: University of Minnesota Press. 